\section{Matters of trust}

$\mathrm{H}$ i Amy," the phone call began, "I'm working ER tonight and there's a guy here with SVC syndrome I think. Could you come by?" I trotted in to the hospital and met George, a patient with a 75-packa-year smoking history, a very large neck and a mass on his chest $\mathrm{x}$-ray. We spoke with the radiation oncologist, who felt radiation was urgent enough to send him down - on December 24 - for treatment. I did some quick explaining to George, and we sent him off to the big city.

A month later, he sat in my office; the tumour had melted away, but I explained the need for a tissue diagnosis. He looked puzzled, but agreed to go back to the teaching hospital for a mediastinoscopy and bronchoscopy. Unfortunately, only necrotic material remained, and I did my best to explain this to George.

A few months later, a supraclavicular node popped up, and one of our general surgeons removed it, for a final diagnosis of small cell lung can- cer. I strongly encouraged George to consider chemotherapy, and told him I would be happy to organize a referral to the oncologist.

"Look doc," he interrupted politely, "I don't read, and I don't write much, but if you tell me what to do, I'll sign my name. But I'm not going back to Edmonton again. I'm sorry my wife is sick and my boy works up at camp." I suddenly realized I had no idea who George was, or what he wanted; and yet, he somehow trusted me. A fearsome thought.

He never met the oncologist in person, only on a television screen. Through telehealth we arranged for his chemotherapy in Yellowknife. He saw me occasionally to discuss side effects, and one spring we discussed his progress. "Doc, when do you think it will come back? Could it be back now?"

I had learned at least enough to ask him why he brought up the question now. "Well, doc, every summer I go out and cut wood. I have a little cabin; it costs maybe $\$ 2000$ to get it up-and-running for the summer. There's not much out there; no neighbours or anything, and I take my own propane and food. I maybe cut enough wood to break even."

The large man leaned forward on his chair, and his voice intensified. "You wouldn't believe the birds out there, doc. In the evening, I just sit and watch them, and listen to them singing all night long. They don't have those kinds of birds in town - every colour you could imagine! I'd love to have another summer out there, but if I get sick again I can't afford to start up the camp for nothing."

My eyes were full as I signed the chest $\mathrm{X}$-ray requisition, hoping I could reassure him and wish him a good summer. The birds would make everything else worthwhile. - Amy Hendricks MDCM, Yellowknife NWT

CMAJ invites contributions to Dispatches from the medical front, in which physicians and other health care providers can provide eyewitness glimpses of medical frontiers, whether defined by location or intervention. The frequency of the section will be conditional on submissions, which must run a maximum 350 words or be subject to our ruthless editorial pencils. Forward submissions to: Wayne.Kondro@cma.ca

DOI:I0.1503/cmaj.071054

\section{Legal actions against doctors}

\section{down $50 \%$ in past decade}

Published at www.cmaj.ca on Aug. 23, 2007.

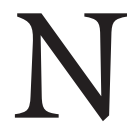
ew challenges face Canada's doctors, and "our environment is likely to become more, not less threatening," Dr. Peter Fraser told the annual meeting of the Canadian Medical Protective Association on Aug. 22 in his last report as outgoing president.

The event in Vancouver focused on the increased risk of liability from factors ranging from new technologies to wait lists. The meeting of the not-forprofit mutual defence organization was followed by a combined session with the Canadian Medical Association (CMA) to discuss wait times and medical liability.
The good news is that legal actions against physicians have declined over the past decade, reported Fraser, from about 26 per 1000 members to 13 per Iooo members.

"Our members are roughly half as likely to be involved in a legal action than they were ro years ago," he said, attributing the cause to "the growing emphasis on patient safety, risk management and the prevention of adverse events."

But the bad news is that system costs of medical liability have increased, he said, with annual damages and legal and expert administration costs rising from about $\$ 170$ million in I 997 to more than $\$ 400$ million in 2006. The median damage cost increased from more than $\$ 30000$ in I996 to nearly \$100 ooo in 2006.

Fraser also warned about a trend of "increasing intrusions on a physician's right to due process" in the name of patient safety, and stressed that the association believes that professional accountability, liability and support to patient safety "are separate but supporting functions."

The association has 7I I64 members, with membership increasing at about 3.6\% per year, reported Dr. Guy Gokiert, chair of the association's audit committee.

Membership growth from among international medical graduates now working in Canada was raised as a related concern. Increasing numbers of members are newly-licensed, "in some cases without rigorous speciality exams based on past training. ... I believe this may present us with some risk," said former CMA President Dr. Albert Schumacher of Windsor, Ont. "There may be a perception that the quality of some members ... is different from what the members until now have been." 